\title{
Co-administration of Cisplatin and Furosemide Causes Rapid and Massive Loss of Cochlear Hair Cells in Mice
}

\author{
Yongqi Li, \\ Center for Hearing and Deafness, University at Buffalo, 137 Cary Hall, Buffalo, NY 14214, USA \\ The Third Affiliated Hospital of Sun Yat-Sen University, Guangzhou, China \\ Dalian Ding, \\ Center for Hearing and Deafness, University at Buffalo, 137 Cary Hall, Buffalo, NY 14214, USA \\ Haiyan Jiang, \\ Center for Hearing and Deafness, University at Buffalo, 137 Cary Hall, Buffalo, NY 14214, USA \\ Yong Fu, and \\ Center for Hearing and Deafness, University at Buffalo, 137 Cary Hall, Buffalo, NY 14214, USA \\ The First Affiliated Hospital, College of Medicine, Zhejiang University, Hangzhou, China \\ Richard Salvi \\ Center for Hearing and Deafness, University at Buffalo, 137 Cary Hall, Buffalo, NY 14214, USA \\ Richard Salvi: salvi@buffalo.edu
}

\begin{abstract}
The expanding arsenal of transgenic mice has created a powerful tool for investigating the biological mechanisms involved in ototoxicity. However, cisplatin ototoxicity is difficult to investigate in mice because of their small size and vulnerability to death by nephrotoxicity. To overcome this problem, we developed a strategy for promoting cisplatin-induced ototoxicity by coadministration of furosemide a loop diuretic. A dose-response study identified $200 \mathrm{mg} / \mathrm{kg}$ of furosemide as the optimal dose for disrupting the stria vascularis and opening the blood-ear barrier. Our analysis of stria pathology indicated that the optimal period for administering cisplatin was $1 \mathrm{~h}$ after furosemide treatment. Combined treatment with $0.5 \mathrm{mg} / \mathrm{kg}$ of cisplatin and $200 \mathrm{mg} /$ $\mathrm{kg}$ furosemide resulted in only moderate loss of outer hair cells in the basal $20 \%$ of the cochlea, only mild threshold shifts and minimal loss of distortion product otoacoustic emission (DPOAE). In contrast, $1 \mathrm{mg} / \mathrm{kg}$ of cisplatin plus $200 \mathrm{mg} / \mathrm{kg}$ of furosemide resulted in a permanent $40-50 \mathrm{~dB}$ elevation of auditory brainstem response thresholds, almost complete elimination of DPOAE, and nearly total loss of outer hair cells. The widespread outer hair cell lesions that develop in mice treated with cisplatin plus furosemide could serve as extremely useful murine model for investigating techniques for regenerating outer hair cells, studying the mechanisms of cisplatin and furosemide ototoxicity and assessing the perceptual and electrophysiological consequences of outer hair cell loss on central auditory plasticity.
\end{abstract}

\section{Keywords}

Ototoxicity; Cisplatin; Furosemide; Cochlea; Hair cell; Mouse

\footnotetext{
(C) Springer Science+Business Media, LLC 2011

Correspondence to: Richard Salvi, salvi@buffalo. edu.
} 


\section{Introduction}

Cisplatin is a widely used antineoplastic drug that has proven highly effective in treating many types of cancers including neuroblastoma, osteosarcoma, testicular, and head and neck tumors. Unfortunately, ototoxicity is one of the major side effects of cisplatin treatment which hinders its use in the clinic. The incidence of cisplatin ototoxicity generally varies from 20 to 50\% with some as high as $70 \%$ depending on the age, cumulative dose, and criteria used to define a significant hearing loss (Coradini et al. 2007; Schell et al. 1989; Skinner 2004; Zuur et al. 2007). The ototoxic symptoms of cisplatin include tinnitus, impaired speech discrimination, and sensorineural hearing loss; hearing loss begins at high frequencies and progresses toward the low frequencies with increased dose and duration of treatment (Blakley et al. 1994; Hill et al. 2008; Laurell and Jungnelius 1990). Among young patients treated with cisplatin, $61 \%$ developed hearing loss and $25 \%$ needed hearing aids after treatment (Knight et al. 2005). Cisplatin damages three major regions of the inner ear, the organ of Corti which contains the sensory hair cells, the spiral ganglion neurons (SGN) in the modiolus, and the stria vascularis in the lateral wall of the cochlea (Ding et al. 2008). Sensory hair cells appear to be most susceptible to cisplatin damage; however, pathological changes can occur in other cell types in the cochlea. While the mechanisms underlying cisplatin ototoxicity are not fully understood, a good deal of evidence suggests that many cell types die by apoptosis. Oxidative stress, DNA damage, and inflammatory cytokines play important roles in triggering apoptosis and the molecular pathways mediating cell death involve a wide range of upstream and downstream signaling pathways (Coling et al. 2007; Ding et al. 2008, 2010; Jamesdaniel et al. 2008; Park et al. 2009; Rybak et al. 2007; Schmitt et al. 2009; Wang et al. 2004; Zhang et al. 2003).

There is growing recognition that genetic factors play an important role in cisplatin-induced ototoxicity (Huang et al. 2007; Oldenburg et al. 2007, 2008; Peters et al. 2000; Riedemann et al. 2008; Ross et al. 2009). Moreover, different animal species used in studies of ototoxicity show considerable diversity in their susceptibility to cisplatin and other platinum-based drugs (Blakley et al. 2008; Ding et al. 1999; Poirrier et al. 2010). With the ever increasing number of genetic mutant mice and the proliferation of transgenic mice, mouse models have become an increasingly powerful tool to gain insights into the mechanisms underlying ototoxicity, susceptibility to ototoxic drugs, the search for otoprotective compounds, and gene therapies to promote hair cell regeneration and reverse hearing loss. While mutant and transgenic mouse models offer many advantages for investigating the molecular mechanisms involved in ototoxicity, previous attempts to use mice to study cisplatin ototoxicity have been disappointing because high doses of cisplatin and carboplatin have more often than not proved lethal while failing to induce permanent hearing loss or cochlear damage (Blakley et al. 2008; Ding et al. 1999; He et al. 2009; Poirrier et al. 2010). The biological mechanisms that make mice resistant to cisplatin ototoxicity are not fully understood, but one factor likely to be involved is the blood-ear barrier which can be temporarily opened by diuretics that damage the stria vascularis (Ding et al. 2007). Ethacrynic acid opens the blood-ear barrier and enhances cisplatin ototoxicity; however, intravenous drug administration can be difficult in mice because of the small size of murine blood vessels. Furosemide, a loop diuretic similar to ethacrynic acid, causes edema of the stria vascularis, disrupts the blood-ear barrier, enhances the entry of ototoxic drugs into the inner ear, and has the advantage that it can be administered intraperitoneally (i.p.) (Ding et al. 2004, 2007; Forge 1976; Oesterle and Campbell 2009; Oesterle et al. 2008; Versnel et al. 2007). In addition, furosemide also appears to reduce the nephrotoxic effects of cisplatin (Heidemann et al. 1985; Santoso et al. 2003). Furosemide is known to potentiate cisplatin-induced hearing loss in guinea pigs (Laurell and Engstrom 1989; McAlpine and Johnstone 1990). However, to our knowledge, the long-term histopathological changes associated with combined treatment of cisplatin plus furosemide are unknown in any 
species. Since it is difficult to induce cochlear lesions in mice with cisplatin alone, the objective of this study was to determine if cisplatin plus furosemide could be used to induce significant hearing loss and cochlear pathology in mice. To develop this model of rapid cisplatin plus furosemide-induced cochlear pathology, we experimented with various dosing strategies that would maximize the hearing loss and ototoxicity while greatly reducing the risk of death. The rationale for developing this murine model is that it could prove useful in studies designed to investigate the mechanisms of cisplatin ototoxicity, the role of various genes in furosemide and/or cisplatin ototoxicity, the effects of outer hair cell loss on cochlear function or central auditory plasticity, and the efficacy of gene therapies for hair cell regeneration.

\section{Methods}

Subjects

CBA/CAJ mice (Jackson laboratory, USA) were used in this study; the numbers used for specific experiments are indicated below. Mice ranged in age between 8 and 12 weeks and weighed between 22 and $35 \mathrm{~g}$.

\section{Auditory Function}

Auditory function was evaluated using the auditory brainstem response (ABR) and distortion product otoacoustic emissions (DPOAE) as described in our earlier reports (Chen et al. 2010; Jamesdaniel et al. 2008). Mice were anesthetized with isoflurane (4\% induction, $1.5 \%$ maintenance) and placed on a temperature-controlled heating pad to maintain normal body temperature. Prior to testing, mice were examined with an otoscope to exclude tympanic membrane perforation, middle ear infection, and debris in the external auditory canal.

\section{ABR Testing}

As reported previously, the active needle electrode was inserted subcutaneously at the vertex, the reference electrode was inserted at the mastoid area of the test ear, and the ground electrode was inserted at contralateral mastoid (Chen et al. 2010). The ABR was elicited with tone bursts $(4,8,12,16,20,32 \mathrm{kHz} ; 0.5 \mathrm{~ms}$ rise/fall time, no plateau, alternating phase) or clicks (10 $\mu \mathrm{s})$ presented at $21 / \mathrm{s}$. Stimuli were generated digitally (TDT system, SigGen, FL, USA), played out through a D/A converter (TDT, RP2.1, $100 \mathrm{kHz}$ sampling rate) and presented through a high-frequency speaker (model: AS-TH400A) located approximately $15 \mathrm{~cm}$ in front of the test ear. The output of the electrodes was led to the head stage of a differential amplifier (TDT, RA4LI), followed by an amplifier (TDT, RA16PA), and then routed by a fiber optic cable to a real-time processor (TDT, RA16BA, $24 \mathrm{kHz}$ sampling rate) that was part of an auditory-evoked response averaging system controlled by TDT software (BioSig). The input signal was amplified $(50,000 \times$, filtered $100-3000 \mathrm{~Hz}$ ), processed with an artifact reject level set at $80 \%$ of full scale, averaged (250 sweeps), and then stored and displayed on a computer. Monaural thresholds were obtained by occluding the contralateral ear with silicone ear molds. Stimulus level was decreased in $10 \mathrm{~dB}$ steps until the response disappeared and then increased in $5 \mathrm{~dB}$ steps in order to bracket the visual detection threshold. The ABR threshold was defined as the lowest intensity that elicited a response.

\section{DPOAE}

As described previously, DPOAEs were recorded at 2F1-F2 using a Smart Distortion Product Otoacoustic Emission System (Intelligent Hearing System, Miami, FL) (Chen et al. 2010). Recordings were performed in a sound attenuating chamber. The earpiece containing 
a microphone (Etymotics 10B+) and two sound delivery tubes was inserted into the ear canal. Two IHS-3738 high frequency transducers (Intelligent Hearing System, Miami, FL, USA) were used to deliver the primary tones, F1 and F2, to the ear canal via flexible tubes connected to the earpiece. The F2/F1 ratio was set at 1.2. The output of the microphone was fed to the input of the DPOAE system, digitized, and evaluated using the system software. DPOAE input/output functions were measured at $\mathrm{F} 2$ frequencies of $8,12,16,20$, and 32 kHz. The intensity of F1 was varied from 35 to $80 \mathrm{~dB}$ SPL in 5-dB steps, and the intensity of F2 was $10 \mathrm{~dB}$ lower than that of F1. At 4, 8, 12, and $16 \mathrm{kHz}$, the output of the microphone was sampled at $40 \mathrm{kHz}$ over a period of $204 \mathrm{~ms}$; the spectrum of each sweep was computed and averaged over 32 non-rejected sweeps. Sweeps with an average noise level $10 \mathrm{~dB}$ above the initially measured noise floor were rejected. The noise floor was measured in a $24-\mathrm{Hz}$ band surrounding $2 \mathrm{~F} 1-\mathrm{F} 2$. At 20 and $32 \mathrm{kHz}$, the output of the microphone was sampled at $127 \mathrm{kHz}$ over a period of $64 \mathrm{~ms}$; the spectrum of each sweep was computed and averaged over 32 non-rejected sweeps. The noise floor was measured in a $46.7-\mathrm{Hz}$ band surrounding 2F1-F2.

\section{Cochleograms}

The procedures for preparing cytocochleograms have been described previously (Ding et al. 2001; Hofstetter et al. 1997). Briefly, animals were killed with an overdose of $\mathrm{CO}_{2}$, decapitated, and the temporal bones quickly removed. The round and oval windows were opened, and $10 \%$ formalin in phosphate buffered saline (PBS) was slowly perfused through the round window for $\sim 1 \mathrm{~min}$; then the cochlea was immersed in $10 \%$ formalin in PBS for $24 \mathrm{~h}$. After decalcification with $1 \mathrm{~N} \mathrm{HCl}$ solution for $12 \mathrm{~h}$, the cochlea was infused with Harris' hematoxylin staining solution for $5 \mathrm{~min}$. The cochlear basilar membrane was dissected out and mounted as a flat surface preparation in glycerin on a glass slide. Specimens were examined under a light microscope (400x), and the numbers of missing inner hair cells (IHCs) and outer hair cells (OHCs) were counted over $0.24 \mathrm{~mm}$ intervals along the entire length of the cochlea. Using lab norms from young, normal CBA mice, cochleograms showing the percent hair cell loss as a function of percent distance from the apex were constructed for each animal. The results from all the mice in the same experimental group were averaged across animals in order to obtain a mean cochleogram for the group. Cochlear position was related to frequency using a cochlear frequency-place map (Müller et al. 2005).

\section{Surface Preparation of Stria Vascularis}

The lateral wall containing the spiral ligament and stria vascularis was carefully removed as described previously (Ding et al. 2002b). The sample was stained with $0.5 \%$ eosin solution for $5 \mathrm{~min}$ and then rinsed with distilled water for $10 \mathrm{~min}$. The surface preparation of the spiral ligament was mounted on a glass slide and examined under a light microscope (Zeiss Axioskop). Surface preparations were photographed with a digital camera (SPOT Insight, Diagnostic Instruments Inc), processed with imaging software (SPOT Software, version 4.6) and images assembled with Adobe Photoshop 5.5.

\section{Sections of Stria Vascularis}

As described in previously, the fixed cochleae were decalcified by immersion in $1 \mathrm{~N} \mathrm{HCl}$ solution for 1 day, dehydrated through a graded series of ethanol solutions ending with 100\%, and embedded in Epon 812 resin (Ding et al. 2001). After polymerization, serial sections were cut in a plane parallel to the modiolus at a thickness of $3 \mu \mathrm{m}$ (Reichert Super Nova microtome) and collected on glass slides. Sections were stained with toluidine blue and examined under a light microscope (Zeiss Axioskop). Specimens were photographed with a digital camera (SPOT Insight, Diagnostic Instruments Inc), processed with imaging software (SPOT Software, version 4.6) and images assembled with Adobe Photoshop 5.5. 


\section{Experiment 1}

The first goal of this experiment was to examine the time course and degree of hearing impairment caused by 100,200 , or $400 \mathrm{mg} / \mathrm{kg}$ (i.p.) of furosemide. Three groups of mice were treated with $100(n=4), 200(n=6)$, or $400(n=5) \mathrm{mg} / \mathrm{kg}$ (i.p.) of furosemide (Phoenix Pharmaceutical INC. St Joseph, MO, USA, NDC 57319-450-05) followed by $1 \mathrm{ml}$ of normal saline (i.p.). Click-evoked ABR thresholds were measured before and 5, 10, and $30 \mathrm{~min}, 1,2,3,6,10$, and $24 \mathrm{~h}$ after furosemide injection. Mice were maintained under isoflurane anesthesia (3\% induction, $1.5 \%$ maintenance) for the first $3 \mathrm{~h}$ so that click ABR thresholds could be measured at 5,10 , and $30 \mathrm{~min}$ and 1,2 , and $3 \mathrm{~h}$ post-treatment. Afterward, the mice were allowed to recover from anesthesia and then briefly $(\sim 10 \mathrm{~min})$ reanesthetized with isoflurane at 6,10 , and 24 h post-treatment to allow click ABR thresholds to be measured at these longer recovery times.

Since some mice died several days after the furosemide treatment, a second group of 26 mice were treated with $100(n=8), 200(n=10)$, or $400(n=8) \mathrm{mg} / \mathrm{kg}$ of furosemide to determine the mortality associated with each dose. Mice were hydrated with $1 \mathrm{ml}$ of lactated ringers (injected subcutaneously, s.c.) on the day of cisplatin injection and daily for the next 3 days. Just prior to furosemide treatment, the mice were anesthetized with isoflurane and maintained under anesthesia for $3 \mathrm{~h}$ as above. The animals were allowed to recover from anesthesia, and the number of animals that survived for 10 days following each treatment was recorded.

\section{Experiment 2}

To determine the effects of continuous or intermittent isoflurane anesthesia on furosemideinduced hearing loss, a total of 12 mice were injected with furosemide $(200 \mathrm{mg} / \mathrm{kg}$, i.p.) followed by $1 \mathrm{ml}$ of normal saline (i.p.). Six of the mice were anesthetized and continuously maintained under isoflurane (3\% induction, $1.5 \%$ maintenance) for $\sim 3 \mathrm{~h}$. Click ABR thresholds were measured from anesthetized mice before and 1, 2, and $3 \mathrm{~h}$ after furosemide treatment. The remaining six mice were temporarily anesthetized as above for $\sim 10 \mathrm{~min}$ per episode in order to obtain click ABR thresholds before and 1,2, and $3 \mathrm{~h}$ after furosemide treatment. Both groups of mice were allowed to recover from anesthesia and then killed $6 \mathrm{~h}$ post-treatment and their cochleas harvested for histological analysis.

\section{Experiment 3}

To evaluate the effects of furosemide on stria vascularis morphology, 18 mice were divided into six groups with three per group. Mice were anesthetized and maintained under continuous isoflurane anesthesia as above; furosemide ( $200 \mathrm{mg} / \mathrm{kg}$, i.p.) followed by $1 \mathrm{ml}$ of normal saline (i.p.) was administered shortly after the induction of anesthesia. Animals were terminated before treatment or 10 and $30 \mathrm{~min}, 1,3$, or $6 \mathrm{~h}$ after furosemide injection. One cochlea from each mouse was prepared as a surface preparation of stria vascularis as described above. The other cochlea from each mouse was decalcified, embedded in Epon, and sectioned as described above.

\section{Experiment 4}

In order to assess the permanent deficits associated with the combination of furosemide plus cisplatin, ABR, DPOAE, and cochleograms were measured 10 days post-treatment. Experiment 4.1 was designed to assess the degree of ABR threshold shifts in three groups: (1) a control group $(n=6)$, (2) a group treated with furosemide (200 mg/kg, i.p.; $1 \mathrm{ml} /$ day, days $1-3)$ followed $1 \mathrm{~h}$ later by $0.5 \mathrm{mg} / \mathrm{kg}$ cisplatin ( $n=7$; i.p., Sigma P-4394), and (3) a group treated with furosemide (200 mg/kg, i.p.; $1 \mathrm{ml} /$ day, days $1-3)$ followed $1 \mathrm{~h}$ later by 1 $\mathrm{mg} / \mathrm{kg}$ cisplatin ( $n=4$; i.p.). (Note: We purposely did not include a cisplatin only group 
because in our two previous attempts cisplatin resulted in the death of most mice, accompanied by little or no hair cell damage.) (Ding et al. 1999; He et al. 2009). Treated mice in groups 2 and 3 were anesthetized and maintained under continuous isoflurane anesthesia at normal body temperature for $4 \mathrm{~h}$ as described above. Ophthalmic ointment (Puralube Vet ointment, Dechra Veterinary Product) was put on the cornea to prevent eye dryness. ABR testing of groups 2 and 3 was performed 10 days after furosemide/cisplatin treatment; control mice were tested at the same time.

Experiment 4.2 was designed to assess OHC function by measuring DPOAEs in three groups of mice, one control group $(n=6)$ and two groups ( $n=6 /$ group) treated with furosemide plus cisplatin as described above. DPOAEs were recorded 10 days posttreatment; controls were evaluated at the same time.

After the final hearing testing, the mice were euthanized and the cochleae were quickly removed and fixed with $10 \%$ formalin. One cochlea from each animal was prepared as a flat surface preparation and used to construct a cochleogram for each animal showing the percent hair cell loss as a function of percent distance from the apex as described above.

This research was approved by the Institutional Animal Care and Use Committee at the University of Buffalo and carried out in accordance with National Institutes of Health guidelines.

\section{Results \\ Experiment 1}

To obtain an estimate of the time course and degree of hearing impairment associated with 100,200 , or $400 \mathrm{mg} / \mathrm{kg}$ of furosemide, click ABR thresholds were monitored for the first 24-h post-treatment. Pre-treatment click ABR thresholds were $~ 35 \mathrm{~dB}$ peak SPL for all three groups. Figure 1 shows the mean $( \pm$ SEM) click ABR threshold shifts (relative to pretreatment thresholds) as function of post-administration time for the $100(n=4), 200(n=6)$, and $400(n=5) \mathrm{mg} / \mathrm{kg}$ doses of furosemide. For the 200 and $400 \mathrm{mg} / \mathrm{kg}$ doses, the click ABR threshold shifts rapidly increased (thresholds got poorer) to a maximum threshold shift of $\sim 70 \mathrm{~dB} 30$ min post-treatment (Note: the variance at the higher thresholds shifts was constricted because the maximum output of the system was limited to approximately $100 \mathrm{~dB}$ peak SPL). Click ABR threshold shifts began to recover $2-3 \mathrm{~h}$ post-treatment, and threshold shifts were nearly zero (normal thresholds) $24 \mathrm{~h}$ post-treatment. The time course of hearing impairment following the $100 \mathrm{mg} / \mathrm{kg}$ dose of furosemide paralleled that of the two higher doses. The click ABR threshold shifts reached a maximum value of $\sim 42 \mathrm{~dB}$ at 30 min posttreatment; the maximum was $\sim 26 \mathrm{~dB}$ less than that for the two higher doses of furosemide.

Groups of mice were treated with 100,200 , or $400 \mathrm{mg} / \mathrm{kg}$ of furosemide, and the numbers of mice that died by 10 days post-treatment were used to determine the mortality rates for each dose of furosemide. Seventy-five percent (6 of 8) of the mice treated with $400 \mathrm{mg} / \mathrm{kg}$ of furosemide alone died within 10 days following treatment. Mortality dropped to $20 \%$ ( 2 of 10 ) in the $200 \mathrm{mg} / \mathrm{kg}$ group and $12.5 \%$ (1 of 8 ) in the $100 \mathrm{mg} / \mathrm{kg}$ group. Although there was considerable hearing impairment with both the 200 and $400 \mathrm{mg} / \mathrm{kg}$ doses of furosemide, the mortality rate with the $400 \mathrm{mg} / \mathrm{kg}$ dose was too high and therefore impractical to use in further studies involving cisplatin plus furosemide. Therefore, the $200 \mathrm{mg} / \mathrm{kg}$ dose of furosemide was used for further studies with cisplatin.

\section{Experiment 2}

Isoflurane anesthesia can influence blood flow and noise-induced hearing loss (Kim et al. 2005; Preckel et al. 1998); however, its effects on furosemide-induced hearing loss have not 
been studied. To evaluate the effects of continuous versus intermittent isoflurane anesthesia on furosemide-induced hearing loss, we measured click ABR thresholds before and after furosemide treatment. Pre-treatment click ABR thresholds were obtained from two groups of mice under isoflurane anesthesia; their pre-treatment ABR thresholds ranged from 30 to $32 \mathrm{~dB}$ peak SPL. One group of mice was then treated with furosemide $(200 \mathrm{mg} / \mathrm{kg}$, i.p. $)$ and maintained under continuous isoflurane anesthesia for the next $3 \mathrm{~h}$. Their click ABR threshold increased after furosemide treatment. The click ABR threshold shifts (relative to pre-treatment thresholds) were approximately 63,59 , and $55 \mathrm{~dB}$, respectively, at 1,2 , and 3 $\mathrm{h}$ post-treatment (Fig. 2). The second group of mice was also treated with furosemide and allowed to awaken from anesthesia after ABR pretesting. They were then briefly reanesthetized with isoflurane 1,2 , and $3 \mathrm{~h}$ post-treatment treatment in order to measure their ABR thresholds. Click ABR threshold shifts in the intermittently anesthetized group were approximately 23,13 , and $3 \mathrm{~dB}$, respectively, at 1,2 , and $3 \mathrm{~h}$ post-treatment. Thus, click ABR threshold shifts were roughly $40-50 \mathrm{~dB}$ higher in the continuously anesthetized mice than the intermittently anesthetized mice. These results suggest that continuous anesthesia exacerbates and prolongs the hearing loss from furosemide.

\section{Experiment 3}

To evaluate the effects of furosemide on stria vascularis morphology, mice were anesthetized, treated with furosemide ( $200 \mathrm{mg} / \mathrm{kg}$, i.p., $1 \mathrm{ml}$ saline), and maintained under anesthesia until the time of death (10 and $30 \mathrm{~min}, 1,3$, or $6 \mathrm{~h}$ post-furosemide). Figure 3 shows a series of representative flat surface preparations of the lateral wall from normal controls and furosemide-treated mice killed between $10 \mathrm{~min}$ and $6 \mathrm{~h}$ post-treatment. The eosin-stained surface preparations of the stria vascularis in Fig. 3 illustrate the pronounced time-dependent changes in the capillary beds following furosemide treatment. In normal controls, the extensive network of wide capillaries is densely packed with red blood cells (Fig. 3a). However, $10 \mathrm{~min}$ after furosemide treatment, there was large decrease in the number of red blood cells within the vessels (Fig. 3b). These trends continued to worsen between $30 \mathrm{~min}$ and $1 \mathrm{~h}$ post-treatment when few red blood cells were present in the vessels (Fig. 3c, d). After $3 \mathrm{~h}$, red blood cells started to refill the vessels, but refilling was only partially complete at $6 \mathrm{~h}$ post-treatment (Fig. 3e, f).

Cross sections of plastic embedded specimens of the stria vascularis were evaluated from 3 normal mice and 15 furosemide $(200 \mathrm{mg} / \mathrm{kg}$, i.p.) treated mice. The 15 furosemide treated mice were divided into five groups ( $n=3$ per group) that were terminated at 10 and $30 \mathrm{~min}$, 1,3 , or $6 \mathrm{~h}$ after furosemide injection. One cochlea from each mouse was decalcified, embedded in Epon, and sectioned as described above. The other cochlea from each animal was prepared as a surface preparation of the stria vascularis and spiral ligament of the lateral wall. Figure 4 shows representative cross sections obtained from normal control mice and mice treated with furosemide and killed at the times indicated in each panel. In normal controls, the more darkly stained marginal (M) cell layer and intermediate (I) cell layer can be clearly discerned from the more lightly stained spiral ligament (SL) of the lateral wall (Fig. 4a). Many marginal cells were swollen and protruding into the endolymphatic (EL) space at 10 min post-treatment. In addition, many vacuoles and clear spaces were evident within the marginal and intermediate cell layers and spiral ligament at this time (Fig. 4b). Staining of the marginal and intermediate cell layers and spiral ligament declined between $30 \mathrm{~min}$ and $6 \mathrm{~h}$ post-treatment and the number of vacuoles and clear spaces increased (Fig. $4 c-f)$. Large, pale extrusions were sometimes evident along the surface of the marginal cells facing the endolymph (Fig. 4e, arrow). 


\section{Experiment 4}

ABR thresholds were measured at 4, 8, 12, 16, 20, and $32 \mathrm{kHz}$ in three groups of mice; a normal control group and two groups of mice treated with the combination of furosemide $(200 \mathrm{mg} / \mathrm{kg}$ ) plus $0.5 \mathrm{mg} / \mathrm{kg}$ or $1 \mathrm{mg} / \mathrm{kg}$ of cisplatin. ABR thresholds were measured 10 days post-treatment in order to estimate the degree of permanent hearing loss resulting from the combination of furosemide $(200 \mathrm{mg} / \mathrm{kg}$ ) plus cisplatin $(0.5 \mathrm{or} 1 \mathrm{mg} / \mathrm{kg})$. Mean ABR thresholds in the untreated control mice ranged from $30 \mathrm{~dB}$ SPL at the mid-frequencies (8$20 \mathrm{kHz}$ ) rising to $48 \mathrm{~dB}$ at $4 \mathrm{kHz}$ and $44 \mathrm{~dB}$ at $32 \mathrm{kHz}$ consistent with our previous results from normal controls (McFadden et al. 1999). Figure 5 shows the ABR threshold shifts in two groups treated with furosemide plus cisplatin; threshold shifts were calculated by subtracting the ABR thresholds of the untreated control group from the ABR thresholds of each of the combined treatment groups. Mean ABR threshold shifts in the group treated with $200 \mathrm{mg} / \mathrm{kg}$ furosemide and $0.5 \mathrm{mg} / \mathrm{kg}$ cisplatin ranged from $\sim 12$ to $15 \mathrm{~dB}$ SPL between 4 and $20 \mathrm{kHz}$ and increased to roughly $26 \mathrm{~dB}$ at $32 \mathrm{kHz}$. In contrast, the mean ABR threshold shifts in the group treated with $200 \mathrm{mg} / \mathrm{kg}$ furosemide plus $1 \mathrm{mg} / \mathrm{kg}$ cisplatin ranged from 39 to $45 \mathrm{~dB}$ between 4 and $20 \mathrm{kHz}$ and falling to around $32 \mathrm{~dB}$ at $32 \mathrm{kHz}$. A two-way analysis of variance showed a statistically significant effect of treatment $(P<0.0001)$, frequency $(P<0.0001)$, and frequency by treatment $(P<0.05)$. ABR thresholds at $4,8,12$, 16,20 , and $32 \mathrm{kHz}$ were $39,44,41,45,40$, and $32 \mathrm{~dB}$ higher in the group treated with 200 $\mathrm{mg} / \mathrm{kg}$ furosemide plus $1 \mathrm{mg} / \mathrm{kg}$ cisplatin than the control group. The frequency differences were all statistically significant (Bonferroni post-tests, $P<0.001$ ). ABR threshold at 4,8 , $12,16,20$, and $32 \mathrm{kHz}$ in the group treated with $200 \mathrm{mg} / \mathrm{kg}$ furosemide plus $0.5 \mathrm{mg} / \mathrm{kg}$ cisplatin were $14,13,13,12,15$, and $26 \mathrm{~dB}$ higher than the control group. These differences were all statistically significant (Bonferroni post-tests, $P<0.05$ at $4,8,12,16$, and $20 \mathrm{kHz}$; $P<0.001$ at $32 \mathrm{kHz})$.

DPOAE input/output functions were measured in three groups of mice ( $\mathrm{F} 2$ frequencies of 4 , $8,12,16,20$, and $32 \mathrm{kHz}$ ). One group served as a control group; the other two were treated with furosemide $(200 \mathrm{mg} / \mathrm{kg}$ ) plus $0.5 \mathrm{mg} / \mathrm{kg}$ cisplatin or $1 \mathrm{mg} / \mathrm{kg}$ cisplatin. The treated groups were tested 10 days post-treatment to estimate the permanent effects of the combined treatments. Figure 6 shows the DPOAE input/output functions from the normal control mice $(n=6)$ along with the noise floor. DPOAE input/output functions from the two experimental groups ( $n=6 /$ group) treated with $200 \mathrm{mg} / \mathrm{kg}$ furosemide plus cisplatin $(0.5 \mathrm{or} 1 \mathrm{mg} / \mathrm{kg})$ are shown for comparison. Normal control mice had large DPOAE amplitudes and relatively steep input/output functions from 8 to $20 \mathrm{kHz}$; however, DPOAE amplitudes were smaller and input/output function slopes shallower at $32 \mathrm{kHz}$. In the group treated with $200 \mathrm{mg} / \mathrm{kg}$ furosemide plus $1 \mathrm{mg} / \mathrm{kg}$ of cisplatin, DPOAEs were largely abolished at L2 frequencies of 16, 20, and $32 \mathrm{kHz}$ (Fig. $6 \mathrm{c}-\mathrm{e}$ ), whereas at 8 and $12 \mathrm{kHz}$ the amplitudes were greatly reduced at low intensities, but increased substantially at high intensities (Fig. 6a, b). In the group treated with the combination of $200 \mathrm{mg} / \mathrm{kg}$ furosemide plus $0.5 \mathrm{mg} / \mathrm{kg}$ of cisplatin, DPOAEs were only slightly reduced at 32 and $8 \mathrm{kHz}$ (Fig. 6).

Cochleograms prepared from mice ( $n=6 /$ group) treated with a combination of $200 \mathrm{mg} / \mathrm{kg}$ furosemide plus 0.5 or $1 \mathrm{mg} / \mathrm{kg}$ of cisplatin are shown in Fig. 7. To aid in comparing the anatomical and physiological results, the locations of the test frequencies on the mouse cochleotopic map are indicated on the upper abscissa (Müller et al. 2005). Mice treated with furosemide and $0.5 \mathrm{mg} / \mathrm{kg}$ cisplatin developed $70 \% \mathrm{OHC}$ loss in the extreme base which decreased to less than $10 \% \mathrm{OHC} \sim 70 \%$ of the distance from the apex (Fig. 7a). IHC loss was negligible throughout the cochlea. In contrast, mice treated with $1 \mathrm{mg} / \mathrm{kg}$ cisplatin (Fig. 7b) developed $80-100 \%$ OHC loss in the basal two-thirds (44-100\%). OHC loss decreased to $30 \%$ OHC is the extreme base. Despite the massive loss of OHC, IHC losses were negligible throughout the cochlea. 


\section{Discussion}

Mice and rats are widely used in auditory research to investigate the biological mechanisms underlying different forms of hearing loss. However, mice offer a major advantage because of the large number of mutant and transgenic strains that can provide insights on the role genetic factors play in noise, drug, and age-related hearing loss (Harding et al. 2005; He et al. 2009; Johnson et al. 1997; McFadden et al. 1999; Ohlemiller et al. 1999; Zheng and Johnson 2001). Cisplatin is a widely used antineoplastic drug that is nephrotoxic and ototoxic. Mechanistic studies of cisplatin ototoxicity are easily accomplished in mouse postnatal organotypic cultures without the complicating problems of nephrotoxicity (Schmitt et al. 2009; Zhang et al. 2007). However, in vivo studies of cisplatin ototoxicity are difficult to conduct in adult mice because most animals die from nephrotoxicity by $4-5$ days posttreatment (He et al. 2009; Watanabe et al. 2002). Moreover, in our previous study, systemic treatment with a single high dose or four consecutive daily doses of cisplatin failed to induce significant cochlear damage or hearing loss (He et al. 2009). Significant damage was only achieved when cisplatin was applied directly to the mouse round window membrane thereby enhancing drug entry into the cochlea.

Cochlear damage can be exacerbated by coadministering loop-inhibiting diuretics such as ethacrynic acid or furosemide with other ototoxic drugs (Ding et al. 2003, 2004, 2007, 2010; Oesterle et al. 2008; Yamane and Nakai 1988). Ethacrynic acid damages the stria vascularis and temporarily opens the blood-cochlear barrier thereby enhancing the entry of ototoxic drugs into the inner ear (Ding et al. 2002a, 2007). We were able to use this barrier-disruption technique to induce significant cochlear pathology in chinchillas by simultaneously coadministering cisplatin and ethacrynic acid (Ding et al. 2007). Because ethacrynic acid is difficult to administer through the extremely thin blood vessels in mice, we switched to intraperitoneal administration of furosemide, which was recently shown to enhance aminoglycoside ototoxicity in mice (Oesterle and Campbell 2009; Oesterle et al. 2008).

\section{Furosemide Mortality}

Our initial studies were conducted with $400 \mathrm{mg} / \mathrm{kg}$ of furosemide since this dose had previously been used to study kanamycin ototoxicity in $\mathrm{CBA} / \mathrm{Cj}$ and Swiss Webster mice. The 400-mg/kg dose caused significant hearing impairment (Fig. 1), but in our hands $75 \%$ of the mice died within the first 10 days post-treatment making this dose impractical to use in long-term survival studies. In contrast, only 12.5 and $20 \%$ of the mice died when treated with 100 and $200 \mathrm{mg} / \mathrm{kg}$ doses of furosemide, respectively. The ABR threshold shifts associated with the $200 \mathrm{mg} / \mathrm{kg}$ dose of furosemide are nearly identical to those obtained with $400 \mathrm{mg} / \mathrm{kg}$ (Fig. 1), but with a substantially lower (20 vs. $75 \%$ ) mortality rate. Thus, the $200-\mathrm{mg} / \mathrm{kg}$ dose of furosemide appears to be the most efficacious and practical to use in coadministration studies.

\section{Dehydration}

Furosemide is a loop-inhibiting diuretic that protects the kidney from cisplatin nephrotoxicity (Guarino et al. 1979; Heidemann et al. 1985; Natochin Yu et al. 1989). The diuretic action of furosemide, however, can lead to severe dehydration. To minimize the effects of dehydration, mice were given $1 \mathrm{ml}$ of lactated ringers (s.c.) for 3 days following treatment with furosemide or furosemide plus cisplatin. In our initial pilot studies, we noticed that the eyes of animals treated with furosemide tended to become dry causing the eyelids to narrow. To retain moisture on the cornea, we applied ophthalmic ointment on the eyes and eyelids prior to administering furosemide; this was especially helpful in minimizing dry-eye problems associated with furosemide treatment. 


\section{Anesthesia}

Previous studies have shown that isoflurane anesthesia protects against noise-induced hearing loss and hair cell loss in BALB/c mice (Kim et al. 2005). In contrast, our results indicate that $3 \mathrm{~h}$ of continuous isoflurane resulted in greater hearing impairment compared to that from intermittent isoflurane anesthesia (Fig. 3). While the mechanisms responsible for increased furosemide-induced hearing loss during isoflurane anesthesia are unclear, we speculate that isoflurane reduces blood flow in the cochlear lateral wall thereby prolonging the repair of the lateral wall of the cochlea and exacerbating the hearing loss. This interpretation is consistent with previous reports showing reduced brain and cochlear blood flow during anesthesia (Brookes et al. 2000, 2002; Koch et al. 2008; Preckel et al. 1998).

\section{Stria Pathology}

The blood vessels in the stria are normally densely packed with red blood cells. Furosemide treatment (Fig. 3) greatly reduced the number of red blood cells in the stria for several hours or more. Cross sections through the stria at $1 \mathrm{~h}$ post-treatment revealed numerous vacuoles throughout the stria vascularis and spiral ligament (Fig. 5). Strial edema began to subside after $3 \mathrm{~h}$, but numerous vacuoles were still present at $6 \mathrm{~h}$ post-treatment. Furosemide causes a sharp decline in oxygen tension in scala tympani, generates toxic free radicals, induces transient ischemia (Clerici et al. 1996; Forge 1976; Humes 1999; Liu et al. 1996), and increases cochlear vessel and strial permeability (Juhn and Rybak 1981; Naito and Watanabe 1997). Moreover, furosemide and ethacrynic acid increase the influx of aminoglycoside antibiotic into the perilymph (Ding et al. 2003; Yamane and Nakai 1988). Therefore, we speculate that furosemide temporarily disrupts the blood-ear barrier thereby promoting the influx of cisplatin from the blood vessels in the lateral wall into the cochlea.

\section{Furosemide Promotes Cisplatin Ototoxicity}

Since the furosemide-induced disruption of the stria peaked $1 \mathrm{~h}$ after the administration of furosemide, we administered cisplatin at this time to maximize entry into scala media. The $0.5-$ and $1-\mathrm{mg} / \mathrm{kg}$ doses of cisplatin were far too low to cause any cochlear damage if applied alone (Ding et al. 1999; He et al. 2009; Poirrier et al. 2010). However, when $1 \mathrm{mg} / \mathrm{kg}$ of cisplatin was administered $1 \mathrm{~h}$ after furosemide treatment, ABR thresholds were permanently elevated $40-50 \mathrm{~dB}$, DPOAE were abolished or greatly reduced, and most of the $\mathrm{OHC}$ were missing over the basal two-thirds of the cochlea. The magnitude of ABR threshold shifts and massive reduction in DPOAE amplitudes are consistent with the view that $\mathrm{OHC}$ play a major role in generating DPOAEs and are responsible for hearing losses of up to $50 \mathrm{~dB}$ (Dallos and Harris 1978; Hofstetter et al. 1997; Ryan and Dallos 1975).

\section{Caveats}

In addition to damaging hair cells, cisplatin is known to be neurotoxic (Bowers et al. 2002; Lee et al. 2003; Walsh et al. 1982; Zhang et al. 2003). A question that remains to be answered is whether the combination of cisplatin and furosemide also results in the degeneration of spiral ganglion neurons. If so, this might limit the utility of this method in studies aimed at restoring auditory function by regenerating hair cells. The mechanisms by which furosemide potentiates cisplatin ototoxicity are not well understood. Our working hypothesis is that furosemide promotes the entry of cisplatin into the cochlear fluids and hair cells thereby enhancing its ototoxic effects; however, further drug uptake studies are needed to test this model. Nevertheless, furosemide is also known to generate reactive oxygen species and to deplete crucial antioxidant enzymes both of which could potentiate cisplatin ototoxicity (Ahokas et al. 1985; Byun et al. 2005; Clerici et al. 1996; Grewal et al. 1996). These two effects represent alternative mechanisms by which furosemide could enhance the ototoxic effects of cisplatin. Finally, the use of isoflurane anesthesia creates an additional 
variable that complicates our understanding of how furosemide enhances cisplatin ototoxicity.

\section{Summary}

The expanding arsenal of mutant and transgenic mice make them an increasingly powerful tool to investigate the genetic and biological mechanisms of cisplatin ototoxicity. However, cisplatin ototoxicity is difficult to study in vivo in these mice because most animals die from nephrotoxicity (He et al. 2009; Watanabe et al. 2002). To overcome this problem, we have developed a dosing strategy using furosemide combined with cisplatin that results in massive OHC lesions, nearly complete loss of DPOAE and ABR threshold shifts on the order of $40-45 \mathrm{~dB}$. The vast majority $(\sim 85 \%)$ of the mice survived for more than 10 days following this combined treatment. The cochlear pathologies resulting from furosemidecisplatin treatment could prove useful in studies designed to assess the effects of selective OHC loss on auditory perception, cochlear function, central auditory system plasticity, or gene therapy designed to regenerate $\mathrm{OHC}$ (Izumikawa et al. 2005).

\section{Abbreviations}

$\begin{array}{ll}\text { ABR } & \text { Auditory brainstem response } \\ \text { ANOVA } & \text { Analysis of variance } \\ \text { dB SPL } & \text { Decibels sound pressure level } \\ \text { DPOAE } & \text { Distortion product otoacoustic emissions } \\ \text { IHC } & \text { Inner hair cells } \\ \text { i.p. } & \text { Intraperitoneal } \\ \text { OHC } & \text { Outer hair cells } \\ \text { s.c. } & \text { Subcutaneous } \\ \text { SGN } & \text { Spiral ganglion neurons }\end{array}$

\section{Acknowledgments}

This article was supported in part by NIH grant R01DC006630.

\section{References}

Ahokas JT, Nicholls FA, Ravenscroft PJ, Emmerson BT. Inhibition of purified rat liver glutathione Stransferase isozymes by diuretic drugs. Biochem Pharmacol. 1985; 34:2157-2161. [PubMed: 4004933]

Blakley BW, Gupta AK, Myers SF, Schwan S. Risk factors for ototoxicity due to cisplatin. Arch Otolaryngol Head Neck Surg. 1994; 120:541-546. [PubMed: 8172706]

Blakley BW, Hochman J, Wellman M, Gooi A, Hussain AE. Differences in ototoxicity across species. J Otolaryngol Head Neck Surg. 2008; 37:700-703. [PubMed: 19128679]

Bowers WJ, Chen X, Guo H, Frisina DR, Federoff HJ, Frisina RD. Neurotrophin-3 transduction attenuates cisplatin spiral ganglion neuron ototoxicity in the cochlea. Mol Ther. 2002; 6:12-18. [PubMed: 12095298]

Brookes ZL, Brown NJ, Reilly CS. Intravenous anaesthesia and the rat microcirculation: the dorsal microcirculatory chamber. Br J Anaesth. 2000; 85:901-903. [PubMed: 11732528]

Brookes ZL, Brown NJ, Reilly CS. Differential effects of intravenous anaesthetic agents on the response of rat mesenteric microcirculation in vivo after haemorrhage. Br J Anaesth. 2002; 88:255263. [PubMed: 11883388] 
Byun SS, Kim SW, Choi H, Lee C, Lee E. Augmentation of cisplatin sensitivity in cisplatin-resistant human bladder cancer cells by modulating glutathione concentrations and glutathione-related enzyme activities. Br J Urol Int. 2005; 95:1086-1090.

Chen GD, Kermany MH, D'Elia A, Ralli M, Tanaka C, Bielefeld EC, et al. Too much of a good thing: long-term treatment with salicylate strengthens outer hair cell function but impairs auditory neural activity. Hear Res. 2010; 265:63-69. [PubMed: 20214971]

Clerici WJ, Hensley K, DiMartino DL, Butterfield DA. Direct detection of ototoxicant-induced reactive oxygen species generation in cochlear explants. Hear Res. 1996; 98:116-124. [PubMed: 8880186]

Coling DE, Ding D, Young R, Lis M, Stofko E, Blumenthal KM, et al. Proteomic analysis of cisplatininduced cochlear damage: methods and early changes in protein expression. Hear Res. 2007; 226:140-156. [PubMed: 17321087]

Coradini PP, Cigana L, Selistre SG, Rosito LS, Brunetto AL. Ototoxicity from cisplatin therapy in childhood cancer. J Pediatr Hematol Oncol. 2007; 29:355-360. [PubMed: 17551394]

Dallos P, Harris D. Properties of auditory nerve responses in absence of outer hair cells. J Neurophysiol. 1978; 41:365-383. [PubMed: 650272]

Ding DL, Wang J, Salvi R, Henderson D, Hu BH, McFadden SL, et al. Selective loss of inner hair cells and type-I ganglion neurons in carboplatin-treated chinchillas: mechanisms of damage and protection. Ann N Y Acad Sci. 1999; 884:152-170. [PubMed: 10842592]

Ding, D.; McFadden, SL.; Salvi, RJ. Cochlear hair cell densities and inner ear staining techniques. In: Willott, J., editor. The auditory psychobiology of the mouse. Boca Raton, FL: CRC Press; 2001. p. 189-204.

Ding D, McFadden SL, Woo JM, Salvi RJ. Ethacrynic acid rapidly and selectively abolishes blood flow in vessels supplying the lateral wall of the cochlea. Hear Res. 2002a; 173:1-9. [PubMed: 12372630]

Ding D, Stracher A, Salvi RJ. Leupeptin protects cochlear and vestibular hair cells from gentamicin ototoxicity. Hear Res. 2002b; 164:115-126. [PubMed: 11950531]

Ding D, McFadden SL, Browne RW, Salvi RJ. Late dosing with ethacrynic acid can reduce gentamicin concentration in perilymph and protect cochlear hair cells. Hear Res. 2003; 185:90-96. [PubMed: 14599696]

Ding D, Jiang H, McFadden SL, Salvi RJ. Ethacrynic acid is the key for opening of the bloodlabyrinth barrier. Chin J Otol. 2004; 1:42-47.

Ding D, Jiang H, Wang P, Salvi R. Cell death after coadministration of cisplatin and ethacrynic acid. Hear Res. 2007; 226:129-139. [PubMed: 16978814]

Ding D, Qi W, Zhang M, Wang P, Jiang H, Salvi R. Cisplatin and its ototoxicity. Chin J Otol. 2008; 6:125-133.

Ding D, Jiang H, Salvi RJ. Mechanisms of rapid sensory hair-cell death following co-administration of gentamicin and ethacrynic acid. Hear Res. 2010; 259:16-23. [PubMed: 19715747]

Forge A. Observations on the stria vascularis of the guinea pig cochlea and the changes resulting from the administration of the diuretic furosemide. Clin Otolaryngol. 1976; 1:211-219. [PubMed: 1031348]

Grewal KK, Rafeiro E, Racz WJ. Bromobenzene and furosemide hepatotoxicity: alterations in glutathione, protein thiols, and calcium. Can J Physiol Pharmacol. 1996; 74:257-264. [PubMed: 8773404]

Guarino AM, Miller DS, Arnold ST, Pritchard JB, Davis RD, Urbanek MA, et al. Platinate toxicity: past, present, and prospects. Cancer Treat Rep. 1979; 63:1475-1483. [PubMed: 159127]

Harding GW, Bohne BA, Vos JD. The effect of an age-related hearing loss gene (Ahl) on noiseinduced hearing loss and cochlear damage from low-frequency noise. Hear Res. 2005; 204:90 100. [PubMed: 15925194]

He J, Yin S, Wang J, Ding D, Jiang H. Effectiveness of different approaches for establishing cisplatininduced cochlear lesions in mice. Acta Otolaryngol. 2009; 2009:1-9.

Heidemann HT, Gerkens JF, Jackson EK, Branch RA. Attenuation of cisplatinum-induced nephrotoxicity in the rat by high salt diet, furosemide and acetazolamide. Naunyn Schmiedebergs Arch Pharmacol. 1985; 329:201-205. [PubMed: 4040218] 
Hill GW, Morest DK, Parham K. Cisplatin-induced ototoxicity: effect of intratympanic dexamethasone injections. Otol Neurotol. 2008; 29:1005-1011. [PubMed: 18716567]

Hofstetter P, Ding D, Powers N, Salvi RJ. Quantitative relationship of carboplatin dose to magnitude of inner and outer hair cell loss and the reduction in distortion product otoacoustic emission amplitude in chinchillas. Hear Res. 1997; 112:199-215. [PubMed: 9367242]

Huang RS, Duan S, Shukla SJ, Kistner EO, Clark TA, Chen TX, et al. Identification of genetic variants contributing to cisplatin-induced cytotoxicity by use of a genomewide approach. Am J Hum Genet. 2007; 81:427-437. [PubMed: 17701890]

Humes HD. Insights into ototoxicity. Analogies to nephrotoxicity. Ann N Y Acad Sci. 1999; 884:1518. [PubMed: 10842580]

Izumikawa M, Minoda R, Kawamoto K, Abrashkin KA, Swiderski DL, Dolan DF, et al. Auditory hair cell replacement and hearing improvement by Atoh1 gene therapy in deaf mammals. Nat Med. 2005; 11:271-276. [PubMed: 15711559]

Jamesdaniel S, Ding D, Kermany MH, Davidson BA, Knight PR III, Salvi R, et al. Proteomic analysis of the balance between survival and cell death responses in cisplatin-mediated ototoxicity. J Proteome Res. 2008; 7:3516-3524. [PubMed: 18578524]

Johnson KR, Erway LC, Cook SA, Willott JF, Zheng QY. A major gene affecting age-related hearing loss in C57BL/6J mice. Hear Res. 1997; 114:83-92. [PubMed: 9447922]

Juhn SK, Rybak LP. Labyrinthine barriers and cochlear homeostasis. Acta Otolaryngol. 1981; 91:529_ 534. [PubMed: 6791457]

Kim JU, Lee HJ, Kang HH, Shin JW, Ku SW, Ahn JH, et al. Protective effect of isoflurane anesthesia on noise-induced hearing loss in mice. Laryngoscope. 2005; 115:1996-1999. [PubMed: 16319612]

Knight KR, Kraemer DF, Neuwelt EA. Ototoxicity in children receiving platinum chemotherapy: underestimating a commonly occurring toxicity that may influence academic and social development. J Clin Oncol. 2005; 23:8588-8596. [PubMed: 16314621]

Koch M, De Backer D, Vincent JL, Barvais L, Hennart D, Schmartz D. Effects of propofol on human microcirculation. Br J Anaesth. 2008; 101:473-478. [PubMed: 18653494]

Laurell G, Engstrom B. The combined effect of cisplatin and furosemide on hearing function in guinea pigs. Hear Res. 1989; 38:19-26. [PubMed: 2708156]

Laurell G, Jungnelius U. High-dose cisplatin treatment: hearing loss and plasma concentrations. Laryngoscope. 1990; 100:724-734. [PubMed: 2362532]

Lee JE, Nakagawa T, Kim TS, Iguchi F, Endo T, Dong Y, et al. A novel model for rapid induction of apoptosis in spiral ganglions of mice. Laryngoscope. 2003; 113:994-999. [PubMed: 12782811]

Liu JX, Zhou XN, Yuan YG. Effects of furosemide on intracochlear oxygen tension in the guinea pig. Eur Arch Otorhinolaryngol. 1996; 253:367-370. [PubMed: 8858263]

McAlpine D, Johnstone BM. The ototoxic mechanism of cisplatin. Hear Res. 1990; 47:191-203. [PubMed: 2228803]

McFadden SL, Ding D, Burkard RF, Jiang H, Reaume AG, Flood DG, et al. Cu/Zn SOD deficiency potentiates hearing loss and cochlear pathology in aged 129, CD-1 mice. J Comp Neurol. 1999; 413:101-112. [PubMed: 10464373]

Müller M, von Hunerbein K, Hoidis S, Smolders JW. A physiological place-frequency map of the cochlea in the CBA/J mouse. Hear Res. 2005; 202:63-73. [PubMed: 15811700]

Naito $\mathrm{H}$, Watanabe K. Alteration in capillary permeability of horseradish peroxidase in the stria vascularis and movement of leaked horseradish peroxidase after administration of furosemide. ORL J Otorhinolaryngol Relat Spec. 1997; 59:248-257. [PubMed: 9279862]

Natochin Yu V, Reznik LV, Bakhteeva VT, Myazina EM, Brovtsyn VK. Cisplatin: nephrotoxic action in vertebrates and its prevention. Comp Biochem Physiol C. 1989; 94:115-120. [PubMed: 2576725]

Oesterle EC, Campbell S. Supporting cell characteristics in long-deafened aged mouse ears. J Assoc Res Otolaryngol. 2009; 10:525-544. [PubMed: 19644644]

Oesterle EC, Campbell S, Taylor RR, Forge A, Hume CR. Sox2 and JAGGED1 expression in normal and drug-damaged adult mouse inner ear. J Assoc Res Otolaryngol. 2008; 9:65-89. [PubMed: 18157569] 
Ohlemiller KK, McFadden SL, Ding DL, Flood DG, Reaume AG, Hoffman EK, et al. Targeted deletion of the cytosolic $\mathrm{Cu} / \mathrm{Zn}$-superoxide dismutase gene (Sod1) increases susceptibility to noise-induced hearing loss. Audiol Neuro-Otol. 1999; 4:237-246.

Oldenburg J, Kraggerud SM, Cvancarova M, Lothe RA, Fossa SD. Cisplatin-induced long-term hearing impairment is associated with specific glutathione s-transferase genotypes in testicular cancer survivors. J Clin Oncol. 2007; 25:708-714. [PubMed: 17228018]

Oldenburg J, Fossa SD, Ikdahl T. Genetic variants associated with cisplatin-induced ototoxicity. Pharmacogenomics. 2008; 9:1521-1530. [PubMed: 18855538]

Park HJ, Kim HJ, Bae GS, Seo SW, Kim DY, Jung WS, et al. Selective GSK-3beta inhibitors attenuate the cisplatin-induced cytotoxicity of auditory cells. Hear Res. 2009; 257:53-62. [PubMed: 19666099]

Peters U, Preisler-Adams S, Hebeisen A, Hahn M, Seifert E, Lanvers C, et al. Glutathione Stransferase genetic polymorphisms and individual sensitivity to the ototoxic effect of cisplatin. Anticancer Drugs. 2000; 11:639-643. [PubMed: 11081456]

Poirrier AL, Van den Ackerveken P, Kim TS, Vandenbosch R, Nguyen L, Lefebvre PP, et al. Ototoxic drugs: difference in sensitivity between mice and guinea pigs. Toxicol Lett. 2010; 193:41-49. [PubMed: 20015469]

Preckel MP, Ferber-Viart C, Leftheriotis G, Dubreuil C, Duclaux R, Saumet JL, et al. Autoregulation of human inner ear blood flow during middle ear surgery with propofol or isoflurane anesthesia during controlled hypotension. Anesth Analg. 1998; 87:1002-1008. [PubMed: 9806672]

Riedemann L, Lanvers C, Deuster D, Peters U, Boos J, Jurgens H, et al. Megalin genetic polymorphisms and individual sensitivity to the ototoxic effect of cisplatin. Pharmacogenomics J. 2008; 8:23-28. [PubMed: 17457342]

Ross CJ, Katzov-Eckert H, Dube MP, Brooks B, Rassekh SR, Barhdadi A, et al. Genetic variants in TPMT and COMT are associated with hearing loss in children receiving cisplatin chemotherapy. Nat Genet. 2009; 41:1345-1349. [PubMed: 19898482]

Ryan A, Dallos P. Effect of absence of cochlear outer hair cells on behavioural auditory threshold. Nature. 1975; 253:44-46. [PubMed: 1110747]

Rybak LP, Whitworth CA, Mukherjea D, Ramkumar V. Mechanisms of cisplatin-induced ototoxicity and prevention. Hear Res. 2007; 226:157-167. [PubMed: 17113254]

Santoso JT, Lucci JA III, Coleman RL, Schafer I, Hannigan EV. Saline, mannitol, and furosemide hydration in acute cisplatin nephrotoxicity: a randomized trial. Cancer Chemother Pharmacol. 2003; 52:13-18. [PubMed: 12719883]

Schell MJ, McHaney VA, Green AA, Kun LE, Hayes FA, Horowitz M, et al. Hearing loss in children and young adults receiving cisplatin with or without prior cranial irradiation. J Clin Oncol. 1989; 7:754-760. [PubMed: 2715805]

Schmitt NC, Rubel EW, Nathanson NM. Cisplatin-induced hair cell death requires STAT1 and is attenuated by epigallocatechin gallate. J Neurosci. 2009; 29:3843-3851. [PubMed: 19321781]

Skinner R. Best practice in assessing ototoxicity in children with cancer. Eur J Cancer. 2004; 40:23522354. [PubMed: 15519505]

Versnel H, Agterberg MJ, de Groot JC, Smoorenburg GF, Klis SF. Time course of cochlear electrophysiology and morphology after combined administration of kanamycin and furosemide. Hear Res. 2007; 231:1-12. [PubMed: 17475424]

Walsh TJ, Clark AW, Parhad IM, Green WR. Neurotoxic effects of cisplatin therapy. Arch Neurol. 1982; 39:719-720. [PubMed: 6889850]

Wang J, Ladrech S, Pujol R, Brabet P, Van De Water TR, Puel JL. Caspase inhibitors, but not c-Jun NH2-terminal kinase inhibitor treatment, prevent cisplatin-induced hearing loss. Cancer Res. 2004; 64:9217-9224. [PubMed: 15604295]

Watanabe K, Inai S, Jinnouchi K, Bada S, Hess A, Michel O, et al. Nuclear-factor kappa B (NF-kappa B)-inducible nitric oxide synthase (iNOS/NOS II) pathway damages the stria vascularis in cisplatin-treated mice. Anticancer Res. 2002; 22:4081-4085. [PubMed: 12553036]

Yamane H, Nakai Y. Furosemide-induced alteration of drug pathway to cochlea. Acta Otolaryngol Suppl. 1988; 447:28-35. [PubMed: 3055805] 
Zhang M, Liu W, Ding D, Salvi R. Pifithrin-alpha suppresses p53 and protects cochlear and vestibular hair cells from cisplatin-induced apoptosis. Neuroscience. 2003; 120:191-205. [PubMed: 12849752]

Zhang ZY, Zhang Z, Fauser U, Artelt M, Burnet M, Schluesener HJ. Dexamethasone transiently attenuates up-regulation of endostatin/collagen XVIII following traumatic brain injury. Neuroscience. 2007; 147:720-726. [PubMed: 17560042]

Zheng QY, Johnson KR. Hearing loss associated with the modifier of deaf waddler (mdfw) locus corresponds with age-related hearing loss in 12 inbred strains of mice. Hear Res. 2001; 154:45-53. [PubMed: 11423214]

Zuur CL, Simis YJ, Lansdaal PE, Hart AA, Schornagel JH, Dreschler WA, et al. Ototoxicity in a randomized phase III trial of intra-arterial compared with intravenous cisplatin chemoradiation in patients with locally advanced head and neck cancer. J Clin Oncol. 2007; 25:3759-3765.

[PubMed: 17704425] 


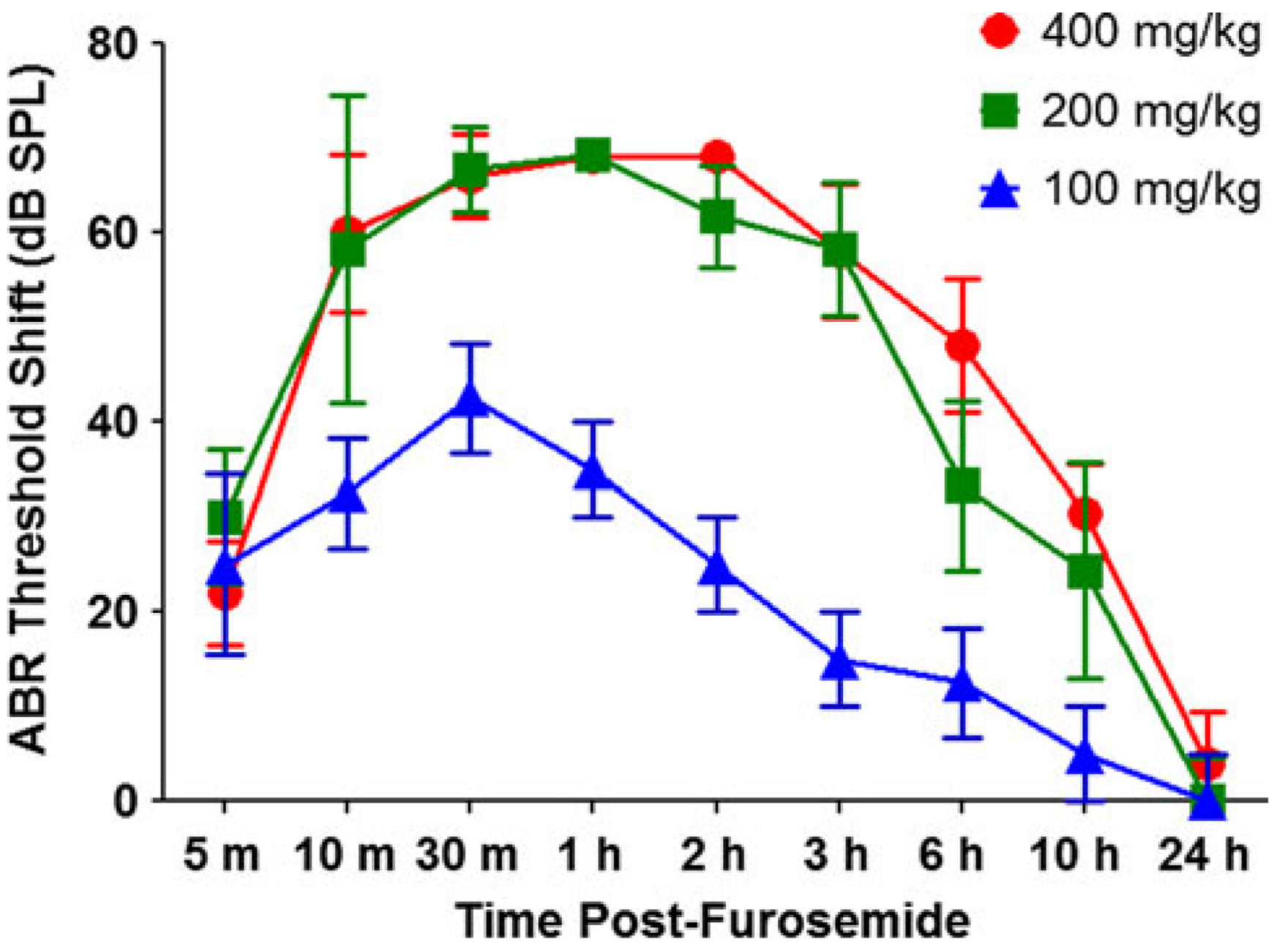

Fig. 1.

Mean ABR click threshold shifts relative to pre-treatment values measured 5 min to $24 \mathrm{~h}$ post-treatment with $100(n=4), 200(n=6)$, or $400(n=5) \mathrm{mg} / \mathrm{kg}$ of furosemide (i.p.). Note that both the 400- and 200-mg/kg doses of furosemide produced large threshold shifts of comparable magnitude, whereas the threshold shifts associated with $100 \mathrm{mg} / \mathrm{kg}$ were considerably lower than the two highest doses. (Note: error bars at 1 and $2 \mathrm{~h}$ with $400 \mathrm{mg} / \mathrm{kg}$ furosemide were very small, since most thresholds were at the limit of the acoustic system) 


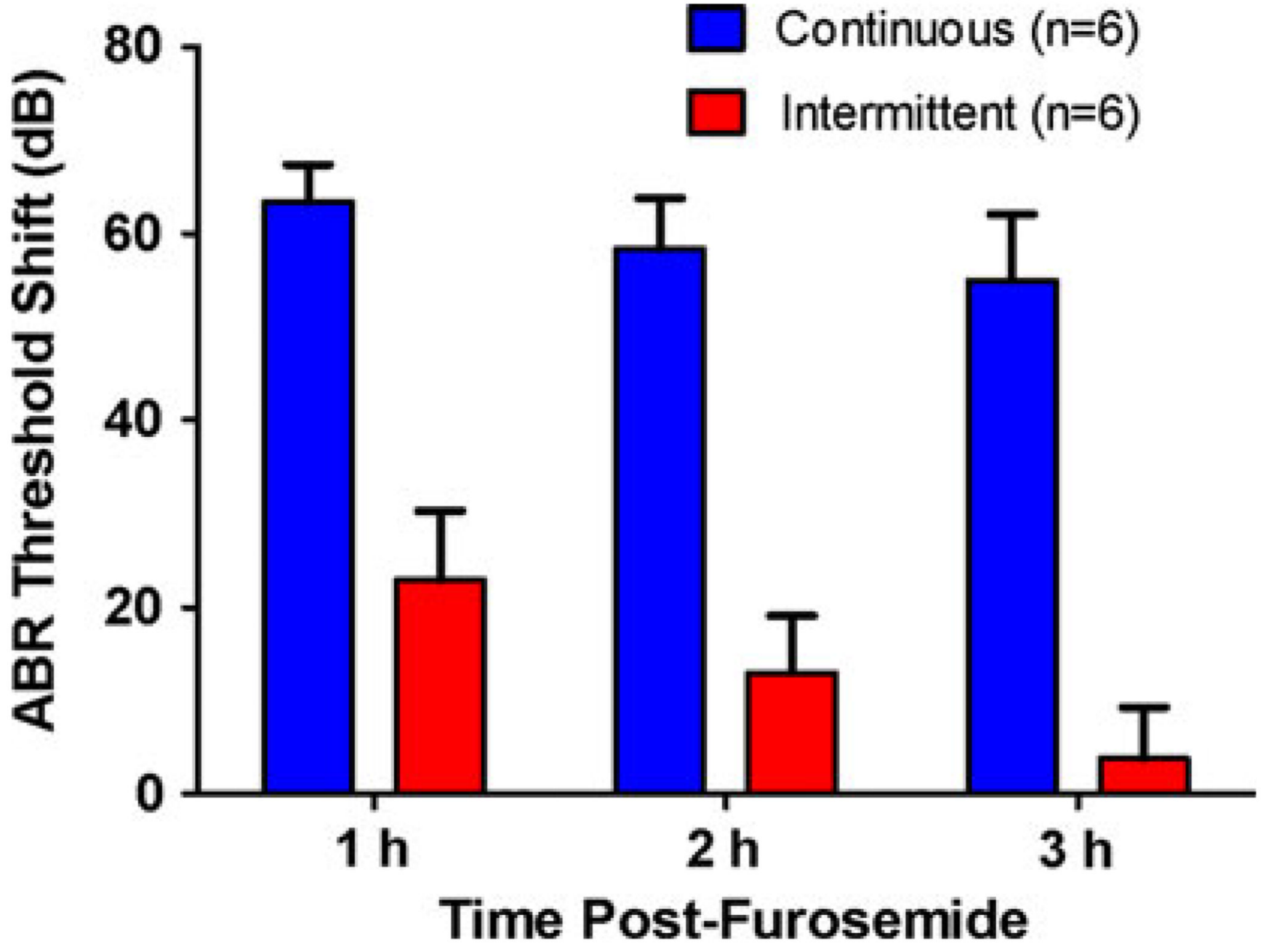

Fig. 2.

Mean click threshold shifts after furosemide $(200 \mathrm{mg} / \mathrm{kg}$, i.p.) treatment in mice tested under continuous or intermittent isoflurane anesthesia 

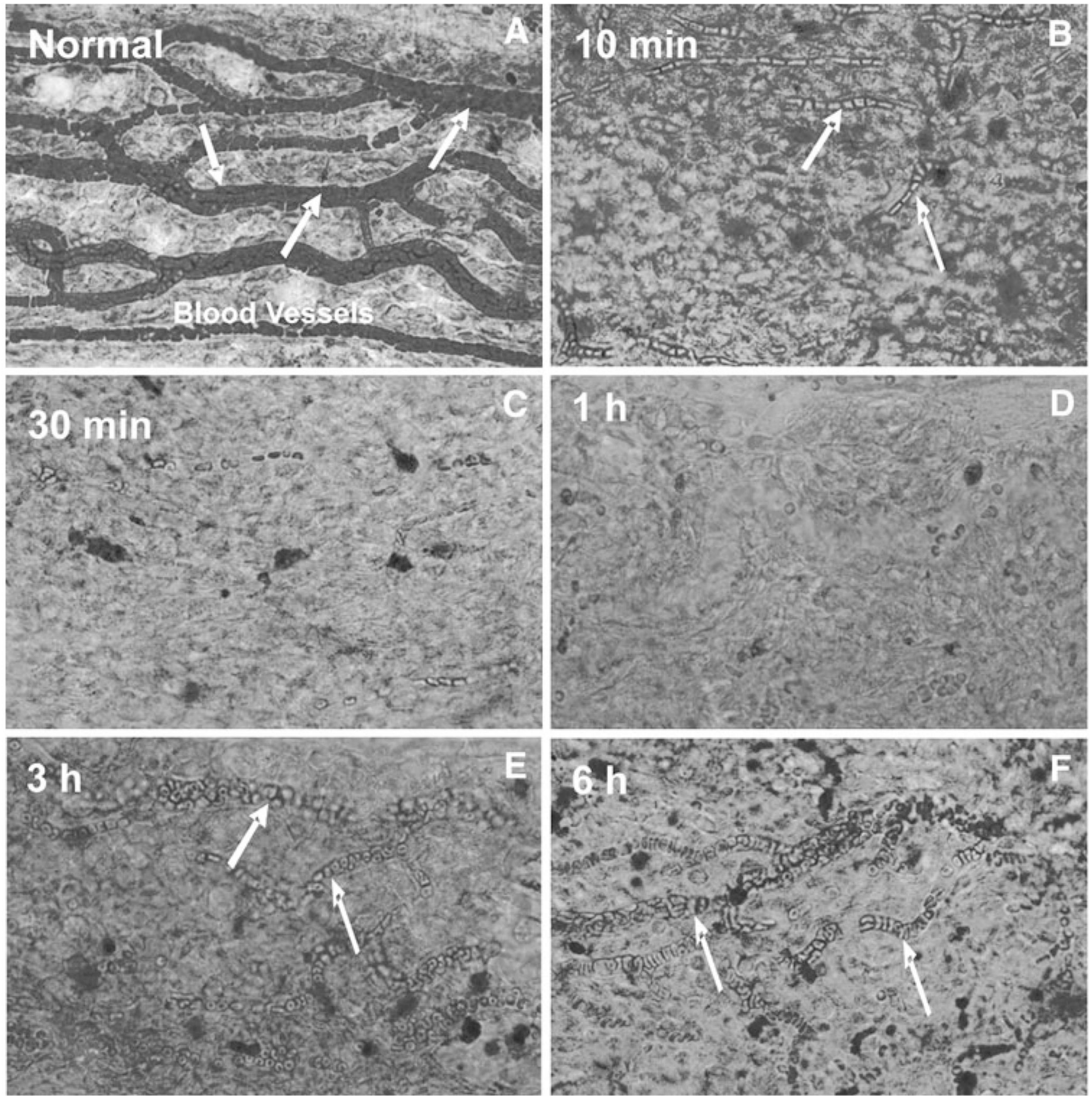

Fig. 3.

Eosin-stained surface preparations of the mouse spiral ligament showing the vessels in the stria vascularis. Representative samples from normal control mice and mice treated with furosemide and evaluated 10,30 min, 1, 3, and $6 \mathrm{~h}$ post-treatment. Vessels in normal control are densely packed with red blood cells (arrows). The number of red blood cells in the vessels begins to decline by 10 min post-treatment; vessels begin to refill with red blood cells around $3 \mathrm{~h}$ post-treatment 
A
B

\section{Normal}

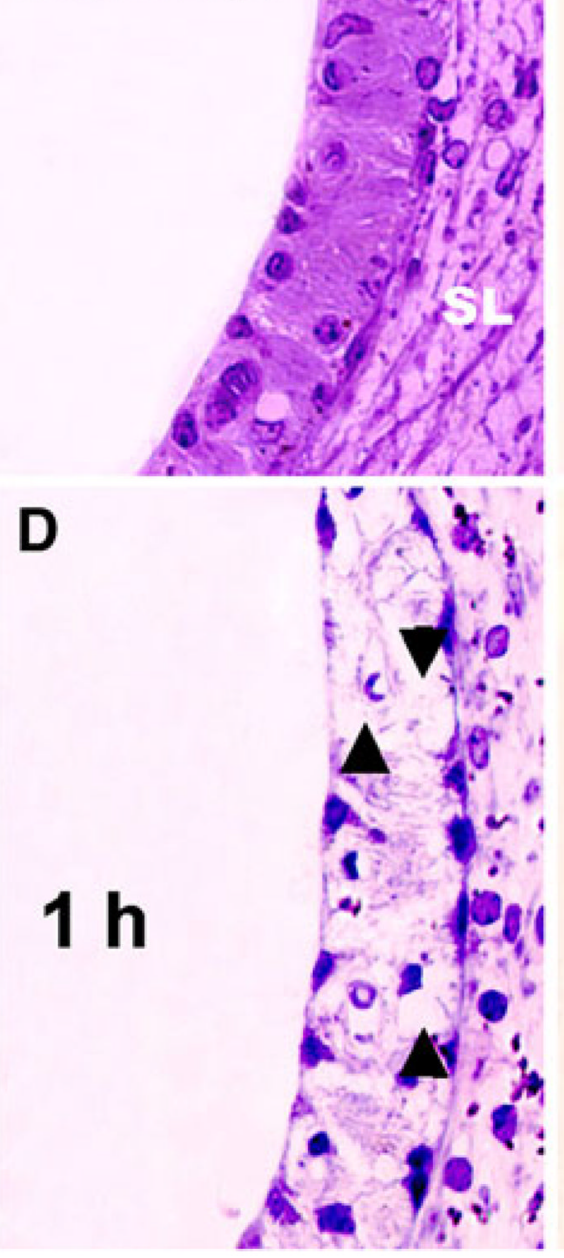

$E L$
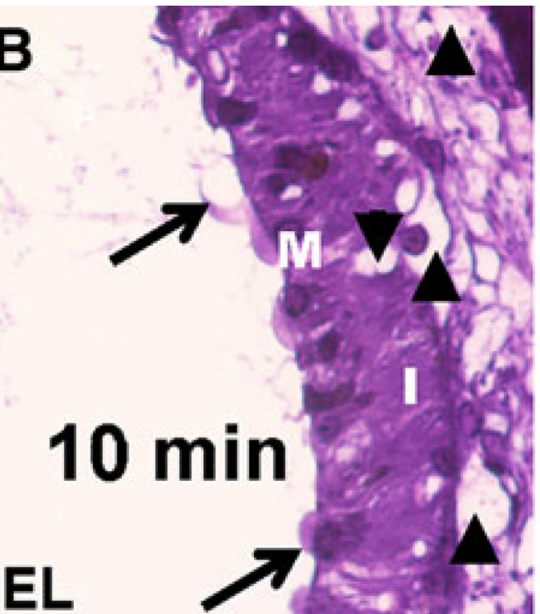

\section{$10 \mathrm{~min}$

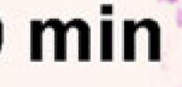
12

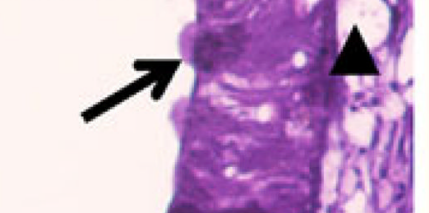

\section{0}



$30 \mathrm{~min}$

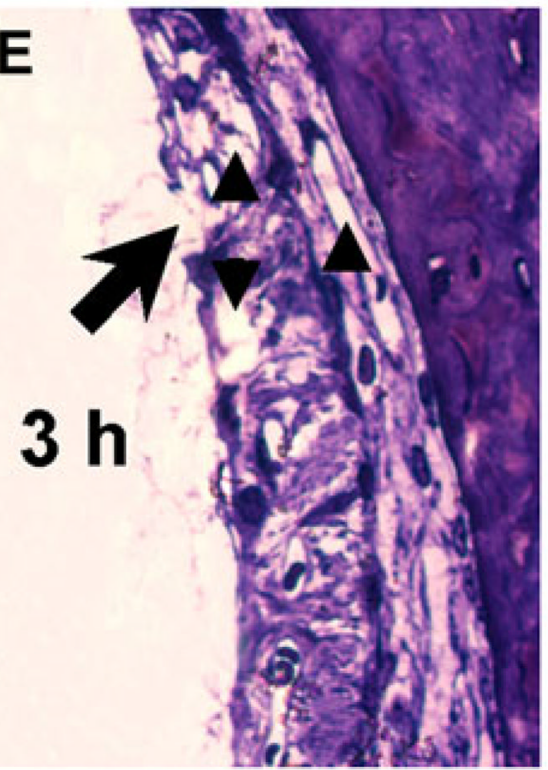

Fig. 4.

Representative cross section of Epon-embedded specimens of the stria vascularis from normal controls (a) and from mice treated with furosemide ( $200 \mathrm{mg} / \mathrm{kg}$, i.p.) and killed a 10 $\min (\mathbf{b}), 30 \mathrm{~min}(\mathbf{c}), 1 \mathrm{~h} \mathrm{(d)}, 3 \mathrm{~h}(\mathbf{e})$, and $6 \mathrm{~h}(\mathbf{f})$ post-treatment. Note the bulging and swelling of marginal cells (M) into the endolymphatic (EL) space and presence of vacuoles in intermediate cells (I) as early as 10 min post-furosemide. Many vacuoles were present within the marginal and intermediate cell layers starting at $10 \mathrm{~min}$, reaching a maximum around $1 \mathrm{~h}$ and starting to subside 3-6 h post-treatment. Large, pale extrusions (black arrow) along the edge of the marginal layer $3 \mathrm{~h}$ post-furosemide 


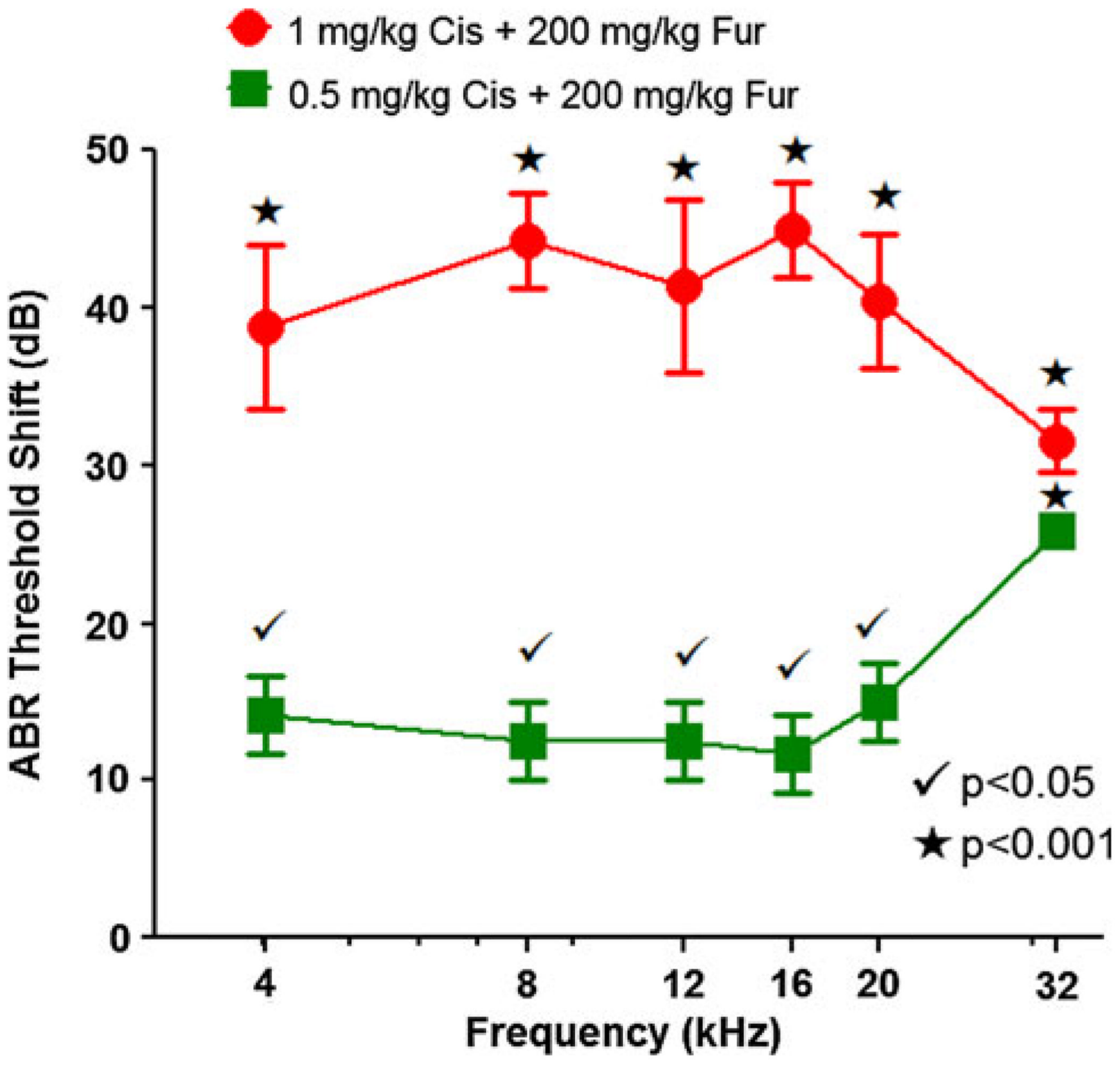

Fig. 5.

ABR threshold shifts plotted as a function of frequency in group 2 treated with $200 \mathrm{mg} / \mathrm{kg}$ furosemide and $0.5 \mathrm{mg} / \mathrm{kg}$ cisplatin and group 3 treated with $200 \mathrm{mg} / \mathrm{kg}$ furosemide and 1 $\mathrm{mg} / \mathrm{kg}$ cisplatin. Thresholds shifts compared to control group $(n=6)$. Main effects of treatment, frequency, and frequency by treatment were statistically significant (two-way ANOVA, $P<0.0001)$. Bonferroni post-tests comparing treated groups versus control group revealed significant differences (see legend) 
A

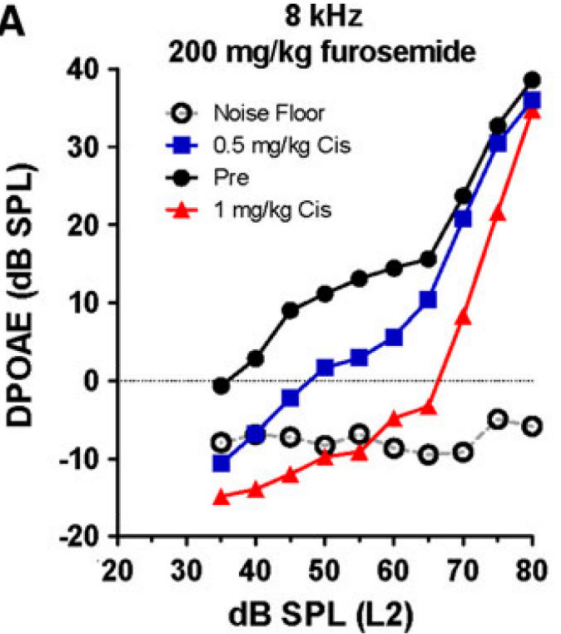

D

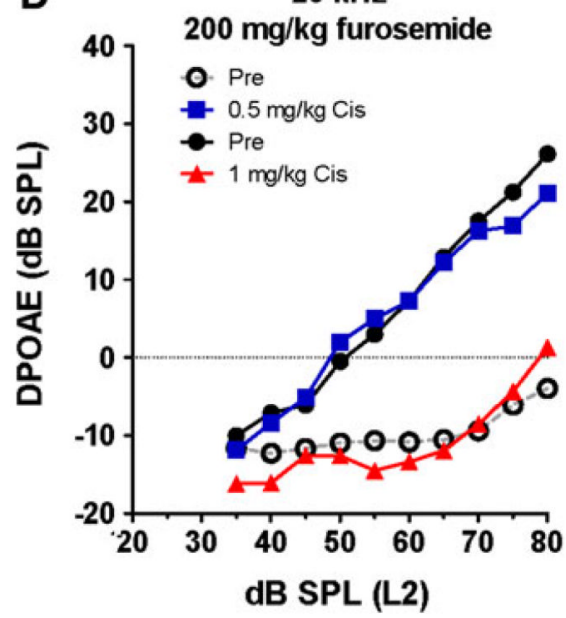

$12 \mathrm{kHz}$

B



E

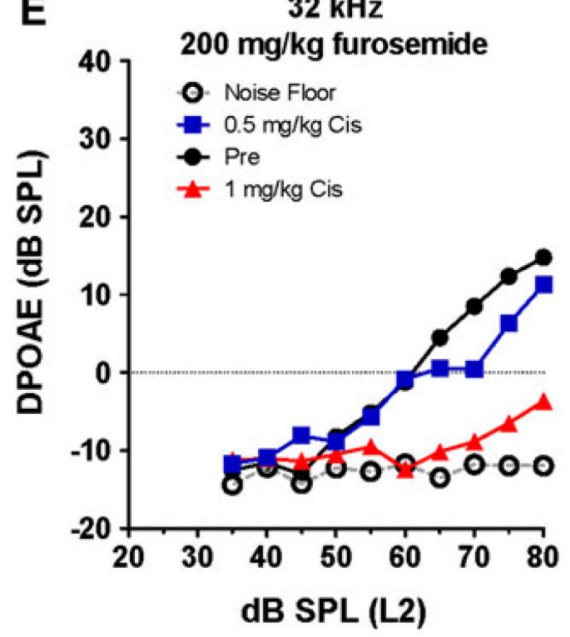

C $\begin{array}{cc}16 \mathrm{kHz} \\ 40 \quad 200 \mathrm{mg} / \mathrm{kg} \text { furosemide }\end{array}$



Fig. 6.

DPOAE input/output functions measured at $\mathrm{F} 2$ frequencies of $4,8,12,16,20$, and $32 \mathrm{kHz}$. Normal DPOAE amplitudes and noise floor (NF) shown for control (Cnt) group $(n=6)$. Experimental groups ( $n=6 /$ group) treated with $200 \mathrm{mg} / \mathrm{kg}$ furosemide plus 0.5 or $1 \mathrm{mg} / \mathrm{kg}$ of cisplatin (Cis) 

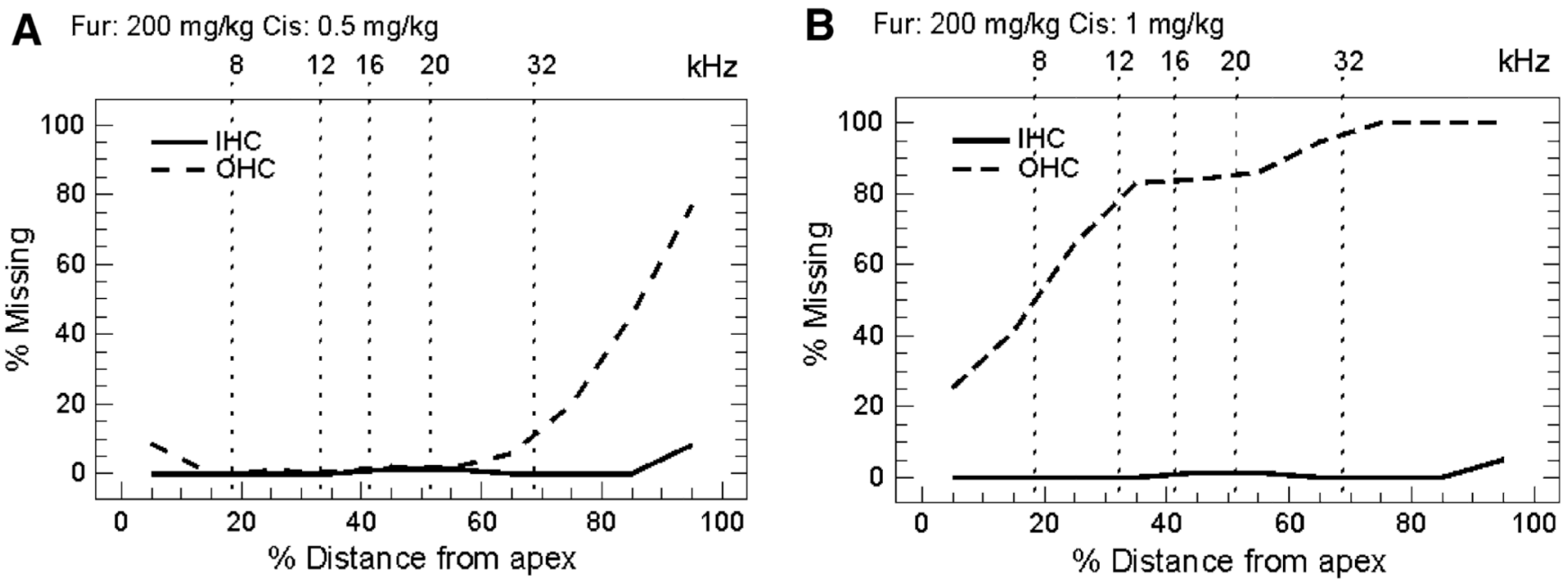

Fig. 7.

Mean cochleograms of mice ( $n=6 /$ group) treated with $200 \mathrm{mg} / \mathrm{kg}$ furosemide (i.p.) combined with a $0.5 \mathrm{mg} / \mathrm{kg}$ cisplatin or b $1 \mathrm{mg} / \mathrm{kg}$ cisplatin 